\title{
The Effect of Technology and Service on Learning Systems During the COVID-19 Pandemic
}

\author{
Arif Ullah ${ }^{1 *}$, Özlem Batur Dinler ${ }^{2}$, Canan Batur Şahin ${ }^{3}$ \\ $1^{*}$ Universiti Tun Hussein Onn Malaysia, Faculty of Computer Science and Information Technology, Johor, Malaysia, (ORCID: 0000-0002-7740-2206), \\ arifullahms88@gmail.com \\ ${ }^{2}$ Siirt University, Faculty of Engineering, Departmant of Computer Engineering, Siirt, Turkey, (ORCID: 0000-0002-2955-6761), o.b.dinler@siirt.edu.tr \\ ${ }^{3}$ Malatya Turgut Özal University, Faculty of Engineering and Natural Sciences, Departmant of Computer Engineering, Malatya, Turkey, (ORCID: 0000-0002-2131- \\ 6368), canan.batur@ozal.edu.tr
}

( $1^{\text {st }}$ International Conference on Applied Engineering and Natural Sciences (ICAENS)- 1-3 November 2021)

(DOI: 10.31590 /ejosat.990073)

ATIF/REFERENCE: Ullah, A., Batur Dinler, Ö. \& Batur Şahin, C. (2021). The Effect of Technology and Service on Learning Systems During the COVID-19 Pandemic. European Journal of Science and Technology, (28), 106-114.

\begin{abstract}
Background/Objectives: The new type of coronavirus disease first appeared in the Wuhan province of China in December 2019. The World Health Organization (WHO) declared this disease a pandemic in February 2020. This pandemic has significantly affected many areas such as education, economy, trade, business life, social life, and primarily health all over the world. In this context, the present study investigates the effect of COVID-19 on the education system. The effect of the COVID-19 pandemic on education systems across the world has caused major changes and shifted the entire curriculum to e-learning systems through online approaches. The study aimed to help universities develop an e-learning platform to facilitate the education of their students under COVID-19 conditions and assess what the role of technology and services would be in learning systems after the COVID-19 pandemic. Approaches: To this end, a review was conducted based on questionnaires from different universities in Morocco. The number of universities consulted, samples, inclusion and exclusion criteria, demographic characteristics of the studied samples, statistical analysis of the obtained results, different suggestions and implementations of learning systems were discussed. Conclusion and future research: This paper shed some light on the growth of e-learning systems during the pandemic and any disasters and provided suggestions for different academic institutions on how to deal with these challenges associated with e-learning.
\end{abstract}

Keywords: COVID-19, Technology, Learning System, Effect of COVID-19, Internet.

\section{COVID-19 Pandemisi Sırasında Teknoloji ve Hizmetlerin Öğrenme Sistemlerine Etkisi}

Öz

Arka Plan/Amaç: Yeni tip koronavirüs hastalığı ilk olarak Çin'in Wuhan eyaletinde Aralık 2019'da ortaya çıktı. Dünya Sağlık Örgütü (DSÖ), bu hastalığı Şubat 2020'de bir pandemi ilan etti. Bu pandemi tüm dünyada başta sağlık olmak üzere eğitim, ekonomi, ticaret, iş hayatı, sosyal hayat gibi birçok alanı önemli ölçüde etkilemiştir. Bu bağlamda, bu çalışma COVID-19'un eğitim sistemi üzerine etkisini araştırmaktadır. COVID-19 pandemisinin dünyadaki eğitim sistemleri üzerine etkisi büyük değişikliklere yol açmış, tüm müfredatı çevrimiçi yaklaşımlarla e-öğrenme sistemlerine kaydırmıştır. Çalışma, üniversitelerin öğrencilerinin COVID-19 koşullarında eğitimlerini kolaylaştırmak için bir e-öğrenme platformu geliştirmelerine yardımcı olmayı ve COVID-19 pandemisi sonrasında teknoloji ve hizmetlerin öğrenme sistemlerindeki rolünün ne olacağını değerlendirmeyi amaçlamıştır. Yaklaşımlar: Bu anlamda Fas'taki farklı üniversitelerden gelen anketlere dayalı olarak bir inceleme yapılmıştır. Danışılan üniversite sayısı, örneklem, dahil etme ve hariç tutma kriterleri, çalışılan örneklemin demografik özellikleri, elde edilen sonuçların istatistiksel analizi, farklı öneriler ve öğrenme sistemleri uygulamaları tartışılmıştır. Sonuç ve gelecekteki araştırmalar: Bu makale, pandemi ve herhangi bir afet sırasında e-öğrenme sistemlerinin gelişimine 1şık tutmuş, farklı akademik kurumlara e-öğrenme ile ilgili bu zorluklarla nasıl başa çıkılacağı konusunda önerilerde bulunmuştur.

Anahtar Kelimeler: COVID-19, Teknoloji, Öğrenme Sistemi, COVID-19'un etkisi, İnternet.

*Corresponding Author: arifullahms88@gmail.com 


\section{Introduction}

The COVID-19 pandemic has challenged education systems and changed the entire world from different aspects. During the COVID-19 pandemic, different countries have addressed the crisis according to their levels. However, education systems in the entire world have shifted to the e-learning mechanism after COVID-19. It was difficult to prepare these learning systems in a short time, especially for countries of the Third World due to the lack of different technologies. In the last five decades, significant growth has been observed in the field of education systems worldwide. However, the COVID-19 pandemic has tested these developments, following which all physical activities have been transformed into virtual systems. For virtualization, different technologies are needed [1]-[2]. It is possible to increase educational productivity with online learning opportunities and the usage of open educational resources and other technologies due to the acceleration of the learning rate [3]. After the emergence of COVID-19, almost 120 countries have closed schools and universities, which affected almost a billion students across the world. Afterward, universities and schools have introduced courses through online portals by adopting different technologies. One of the main advantages of e-learning systems is that postgraduate students are registered as part-time students because they also work in different fields [4]-[5].

\subsection{Effect of COVID-19}

The coronavirus disease 2019 (COVID-19) emerged in December 2019, causing many changes in life and society worldwide. COVID-19 was declared a global public health emergency by the World Health Organization (WHO) on January 30th, 2020, and it became a pandemic. After most of the countries were affected and the number of cases and death ratio increased, the entire world started implementing lockdowns. All activities were closed due to social distancing, and education systems were also affected, causing all universities and schools to be closed. Few months after lockdown, people became familiar with handling COVID-19 and started working from different angles and in different styles by considering different parameters. Each country started working in a different field by following the standard operating procedure (SOP), which they introduced for their people's protection due to the COVID-19 pandemic [6]-[7]. Figure 1 presents the effect of COVID-19 worldwide.

Figure 1: Effect of Covid-19 world-wide (unicef.org)

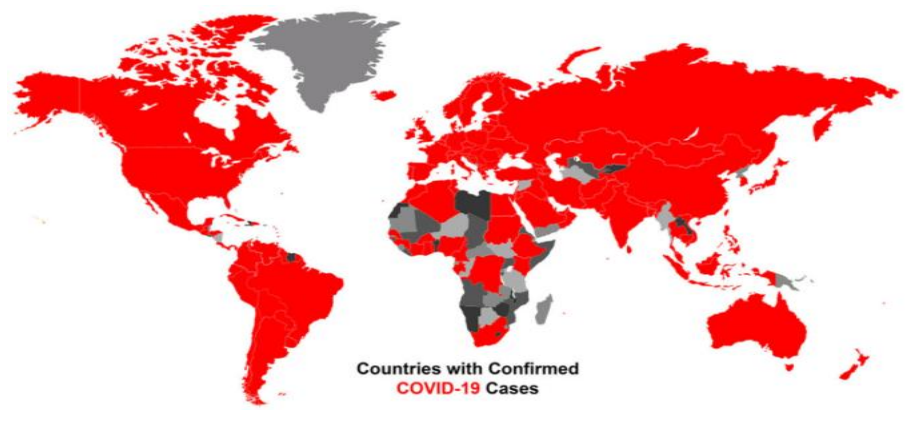

\subsection{Learning Systems After COVID-19}

The domain of education is one of the best examples of changes in the world due to the COVID-19 pandemic. All activities of education systems have been transformed into elearning systems, where all teaching activities have been transferred to online communication and learning platforms. On these platforms, both the teacher and student interact while using different applications for teaching. This is not the first example. In 2009, the traditional education system was stopped due to the H1N1 flu outbreak, which affected the education system. After the COVID-19 pandemic, the face-to-face learning system was changed to distance learning, or simply, to e-learning systems. Many governments tried to keep up with the exponential spread of COVID-19. Thus, there was very limited time for organizations to prepare for a remote teaching regime. If possible, preparations could have been completed, and Figure 2 demonstrates the applications and software used during the COVID-19 pandemic [8]-[10].

Figure 2 shows the different applications and software used by various countries for educational purposes according to their requirements during the COVID-19 pandemic. Due to COVID19 , e-learning is becoming very popular worldwide because almost all activities are performed based on technology via the internet. Online learning or e-learning is effective in developed countries, but it is not effective in most of the underdeveloping countries due to different reasons. One of the main elements of learning systems is smartphones. However, they are not effective in learning due to a significant amount of content that can be accessed using smartphones [12]-[13]. After the survey of organizational agility ( $\mathrm{Wu}, 2020)$, it was observed that online learning systems had several issues, including content change into digital, online teaching methods and different resources used for education systems. Furthermore, the main issues of online systems are the effects and efficacy of online education and the range of learning goals guiding our educational and instructional priorities. The absence of access to quick, cheap and reliable internet connections prevents online learning, particularly for individuals living in rural areas and marginalized communities in different countries [14]. After the COVID-19 pandemic, the student's entire education progress has changed in a different way. For example, different students need to change from schools to universities or colleges to training sections, according to their education level. This changes student's life or encourages different roles in students. However, due to COVID-19, all these activities have been stopped, and only the online system has remained without any social progress[15]-[16]. 
Figure 2: Different Parameters During COVID-19[12].

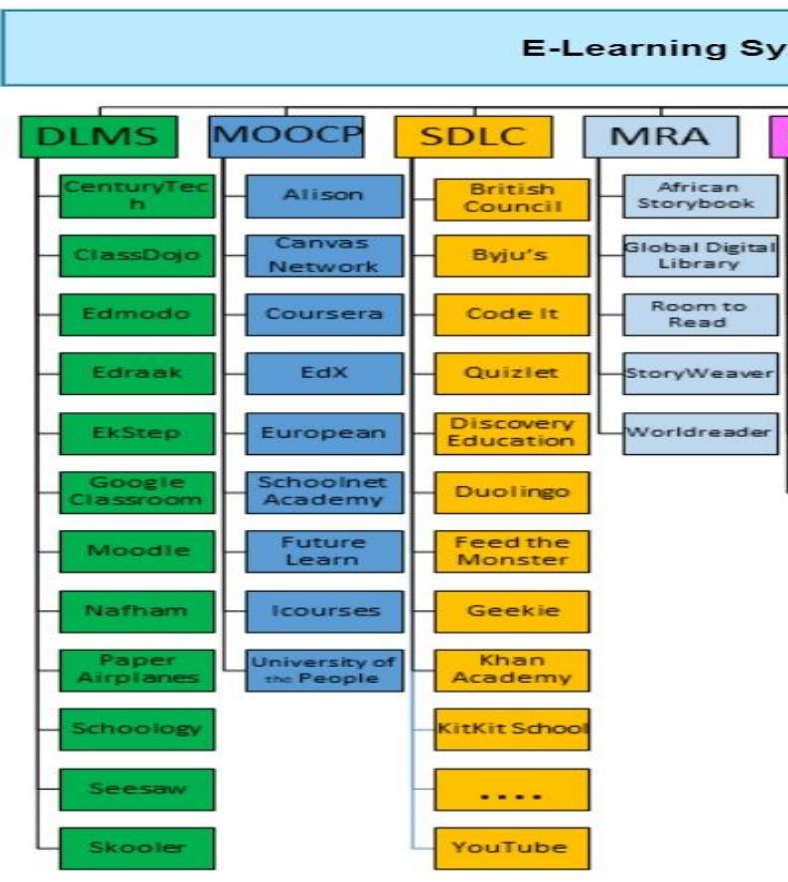

2. Material and Method

\subsection{Current Technologies And Services Used in Learning Systems}

Information and communication technologies (ICTs) have quickly become one of the main supports of today's society. Nowadays, a lot of countries regard understanding the said technologies and becoming proficient in their major concepts and skills as an indispensable part of basic education, along with writing, reading, and arithmetic. Thus, education informatization has become a new paradigm of online education, called smart elearning, that allows for inserting the theory of modern education based on educational data and uses supporting technologies to make better use of intelligent e-learning services [17]-[18]. In this sense, we can speak of two different axes of data-based services, among which online learning is a three-level architecture: the first level is data, the second is supporting technology, and the third level is service. Under the traditional category of data, it is possible to divide educational data into three groups: unstructured data, semi-structured educational data, and structured educational data. The main supporting technologies cover digital tools and products that can be used in education and online teaching. They include typical services, e-learner profiles, generation and navigation of learning paths, and a knowledge graph construction process. In intelligent e-learning, the descriptive analysis makes it possible to target, describe, summarize, and analyze the data historically and educationally and perform typical tasks allowing including the profile of the e-learner and the KG construction. The diagnostic analysis consists of identifying the trends' causes and the learning results of e-learners. As long as the analysis continues, it allows monitoring the e-learner status, resource usage, action, and decision autonomously or semi-autonomously [19]-[20]. The COVID-19 pandemic has affected countless areas of human activity, including education systems, on a large scale worldwide. According to the data of (UNESCO 2020), more than $1500,000,000$ university students, who cannot attend their universities, have been affected. Due to the effect of COVID-19, the education system was shut down. However, after becoming familiar with this problem, UNESCO has recommended equipping educational institutions with online learning tools [21][22]. We live in the age of information technologies, which play a vital role in different fields, and education is one of them. The shift from the classical design of teaching and training, which is approaching in a hidden way, represents a source of both difficulties and opportunities for higher education institutions. Thus, some of the issues in the future education system after the COVID-19 pandemic are discussed in this paper, and results are collected from a questionnaire-based study.

\subsubsection{Problem Statement}

This study was designed to critically examine the effect of technology and service on learning systems during the COVID19 pandemic. The present research investigated its positive and negative impacts on the education system and checked different issues. After COVID-19, technology was included in the education system, and it is required to investigate which section needs improvement and more specific modification with regard to technology and services.

\subsubsection{Objectives of the Study}

- To find positive impacts of technology on the education system during the COVID-19 pandemic.

- To find negative impacts of technology and service on the education system during the COVID-19 pandemic.

- To provide recommendations for improvement of technology and service after the COVID-19 pandemic.

\subsubsection{Hypothesis}

The study is based on the following hypothesis, and Figure 3 presents the theoretical framework of the paper.

Figure 3: Theoretical Framework. 


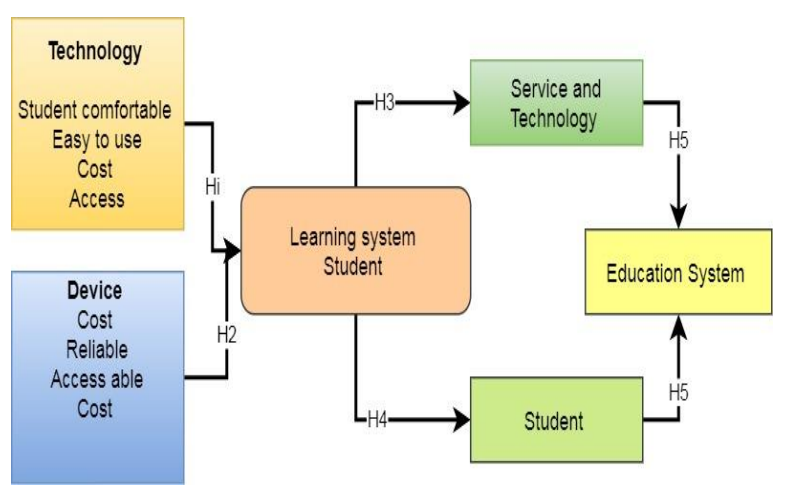

- H1. E-information quality has a caring connotation with students' e-learning.

- H2. Students' e-learning arbitrates the relationship between e-service qualities.

- H3. Students' satisfaction arbitrates the relationship between students' e-learning and university image.

- H4. The relationship between e-learning and the cost of different devices is mediated by students' satisfaction.

- H5. Students' satisfaction with the cost of technology and its future implications.

\subsubsection{Data Collection}

The target population of the current paper consisted of students selected from different public and private universities in Morocco according to their ranking in QS World Ranking 2020. Online questionnaires were employed for data collection from the universities using online education systems continuously under the current COVID-19 conditions. Data collection was performed using an online questionnaire with the help of the Google platform. Three hundred questionnaire responses in total were obtained, and the number of responses that could be used for data analysis was 300 .

\subsubsection{Questionnaire and Methods}

The questionnaire consists of 30 items on the basis of the research of [23]-[24]. The main categories used are technology and communication, consisting of 10 items. The quality of elearning service consists of four dimensions, which were adopted by [25], and the effect of device and connection consists of 3 dimensions adopted by [26].

\subsection{Simulation Environmet}

Structural equation modeling (SEM) is used to conduct multivariate analysis. SEM is a statistical modeling instrument which can solve casual and complex covariance relationships among different variables. It basically represents a set of multivariate techniques, including measurement and structural equation simultaneously [27]-[28]. PLS, LISREL, EQS, and AMOS represent the most common SEM techniques. EQS, LISREL, and AMOS are covariance-based methods, whereas PLS is a component-based technique [29]. SEM is used for covariance in the analysis techniques rather than correlation in other tools such as regression analysis in SPSS, yielding better results compared to correlation [30]-[31]. SEM was used in this study because it evaluates the theoretical proposition, showing the correlation between constructs and the credibility of the theoretical model [32]-[33]. Furthermore, the main advantage of using SEM is the increased application of SEM in performancerelated studies [34]-[35]. The mentioned advantages include its ability to conduct multifaceted and multiple regression analysis as a whole simultaneously, its use for the generation of results. Moreover, the PLS algorithm and bootstrapping technique are used for the measurement of data as well as the structure of the model [36]-[37].

\section{Results and Discussion}

Finally, the results of the paper demonstrate that students are satisfied with the learning system during the COVID-19 pandemic in different universities in Morocco with positive images and few negative images. The above-mentioned findings are important for universities when they start the e-learning of students due to the impact of COVID-19, which causes a paradigm shift in the education sector, especially in universities. In the course of the paradigm shift and the adoption of online learning, universities should concentrate on ICT together with reliability, tangibility, assurance, and responsiveness. Furthermore, when universities start the e-learning of students, they will make use of different services in positive and negative aspects. Thus, through a paradigm shift, universities are able to maintain their operations via online learning as a result of applying the elements mentioned above under the COVID-19 conditions. Table 1 shows the results of the collection after simulation, while Figure 4 demonstrates the simulation process.

Table 1. Data Process.

\begin{tabular}{|c|c|c|c|c|c|c|c|c|c|c|}
\hline & HH1 & HH2 & HH3 & HH1 & HH4 & HH5 & HH2 & HH1 & HH3 & HH4 \\
\hline & 0.533 & & & & & & & & & \\
\hline$S S$ & 0.614 & 0.432 & & & & & & & & \\
\hline$M M$ & 0.899 & 0.56 & 0.584 & & & & & & & \\
\hline$E O$ & 0.571 & 0.511 & 0.545 & 0.561 & & & & & & \\
\hline$S S$ & 0.595 & 0.433 & 0.618 & 0.525 & 0.592 & & & & & \\
\hline$A A$ & 0.552 & 0.471 & 0.38 & 0.854 & 0.462 & 0.262 & & & & \\
\hline$E O$ & 0.589 & 0.415 & 0.654 & 0.543 & 0.497 & 0.626 & 0.335 & & & \\
\hline$M M$ & 0.553 & 0.235 & 0.659 & 0.578 & 0.298 & 0.355 & 0.308 & 0.409 & & \\
\hline Privacy & 0.258 & 0.163 & 0.296 & 0.237 & 0.389 & 0.397 & 0.101 & 0.438 & 0.191 & \\
\hline$S S$ & 0.799 & 0.687 & 0.644 & 0.823 & 0.678 & 0.775 & 0.473 & 0.681 & 0.428 & 0.411 \\
\hline$E O$ & 0.617 & 0.42 & 0.866 & 0.644 & 0.47 & 0.489 & 0.426 & 0.615 & 0.723 & 0.152 \\
\hline$A V A$ & 0.757 & 0.539 & 0.756 & 0.641 & 0.878 & 0.68 & 0.34 & 0.884 & 0.511 & 0.327 \\
\hline
\end{tabular}


Figure 4: Measurement Tool.

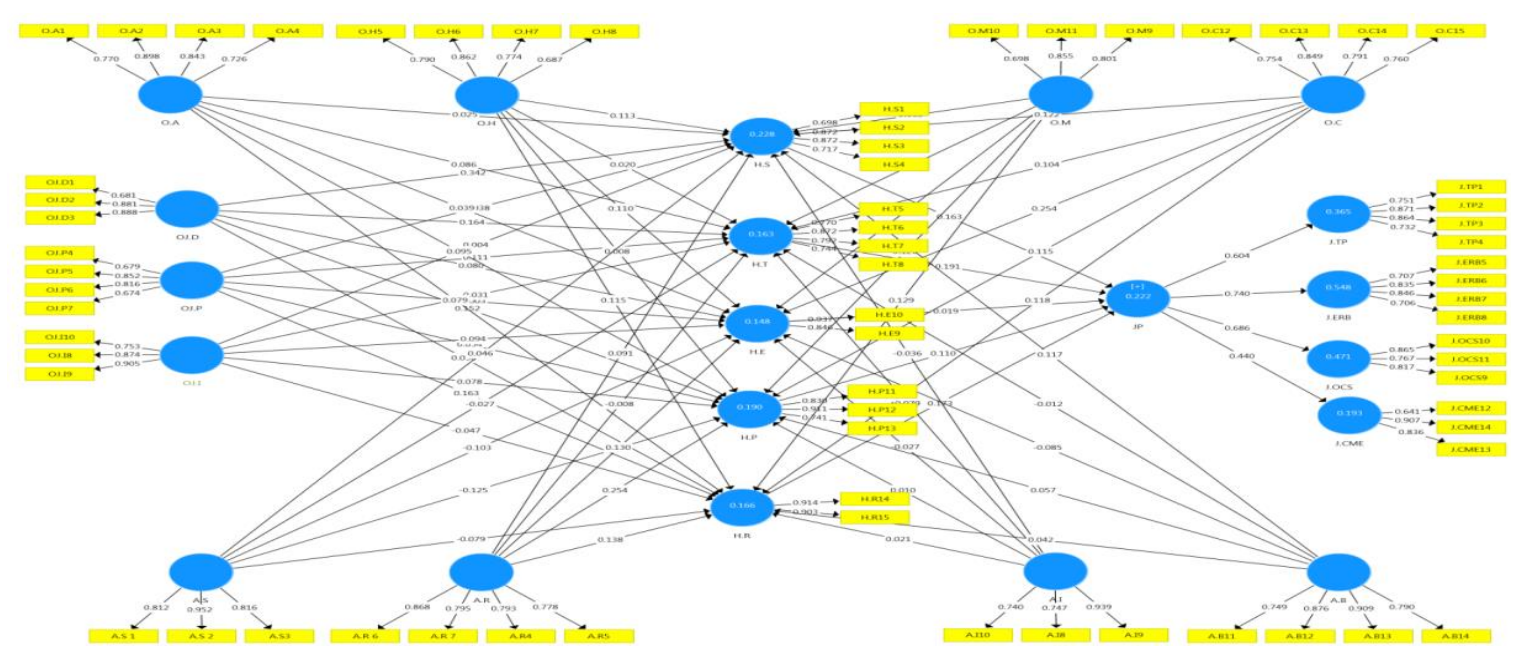

The construct validity is checked by conducting a parallel analysis and is a powerful technique; it measures the components of the factor to be retained after performing the factor analysis. The current study confirmed that students were satisfied with the vital components of online education in an emergency, such as the COVID-19 pandemic. The three main elements of the system are technology, services and devices, and their quality. These studies have a positive aspect in improving education systems during this pandemic and some negative aspects about the service quality and cost.

The present research suggested that the e-learning of students was one of the essential components of providing online education in an alternative condition, such as the COVID-19 pandemic. Nevertheless, the e-learning of students includes three main elements: e-service, quality, and e-information quality. The findings of the research emphasized that technology and service played an affirmative role in improving the e-learning of students. The development of students' e-learning is possible with better technology and service. Previous research also supports the mentioned findings. In accordance with [38], technology and service play a primary role in promoting students' e-learning. Moreover, further research confirms a significant positive impact of technology and service on the e-learning of students [39]-[40]. Additionally, the study findings also confirmed that the quality of e-service contributed positively to promoting the e-learning of students. Thus, the quality of e-service quality represents the central component of the paradigm shift. Higher e-service and resource quality can assist with the paradigm shift in universities. A higher quality of e-service may encourage students to learn using an online system. In line with the present research, [41] argued that the quality of e-service had a direct effect on the faithfulness of e-learning students. In consistency with this research, different previous studies also emphasized that the quality of e-service and resources positively affected the e- learning of students [42]. Moreover, the current research demonstrated that the quality of e-service should have perceptibility, dependability, receptiveness, and declaration for the purpose of encouraging the e-learning of students. Furthermore, it is necessary to ensure a higher quality of einformation with the aim of providing a better student e-learning system. E-learning quality is dynamic for the purpose of developing a students' e-learning system and motivating students to benefit from the online learning facility. Prior studies in the literature are also parallel with the present research and provide pieces of evidence indicating that the quality of e-information has a positive effect on improving students' e-learning. Previous research has examined a significant positive impact of einformation on the learning of students [43]. In parallel with this research, different previous studies also emphasized that the quality of e-service positively affected a students' e-learning system. Moreover, the present research confirmed that e-service quality should possess reliability, tangibility, assurance, and responsiveness for the purpose of promoting the e-learning of students. In addition, it is necessary to ensure a higher quality of e-information with the aim of providing a better student e-learning system. The third section discusses the cost and connection procedures students are uncomfortable with. The fifth section discusses the real time section and privacy and service section (SS), which are the main issues that need to be solved in the future. The last section states that more studies are needed on the same platform (AVA) for sharing different contents with different students. The survey indicated positive results or images during the COVID-19 pandemic. However, few main suggestions were made. For example, an improvement is needed after the COVID19 pandemic, when different organizations design different platforms for learning systems. Figures 5 and 6 show the impact of COVID-19 on the education system. 
Figure 5: Positive impact of COVID-19 on the learning system.

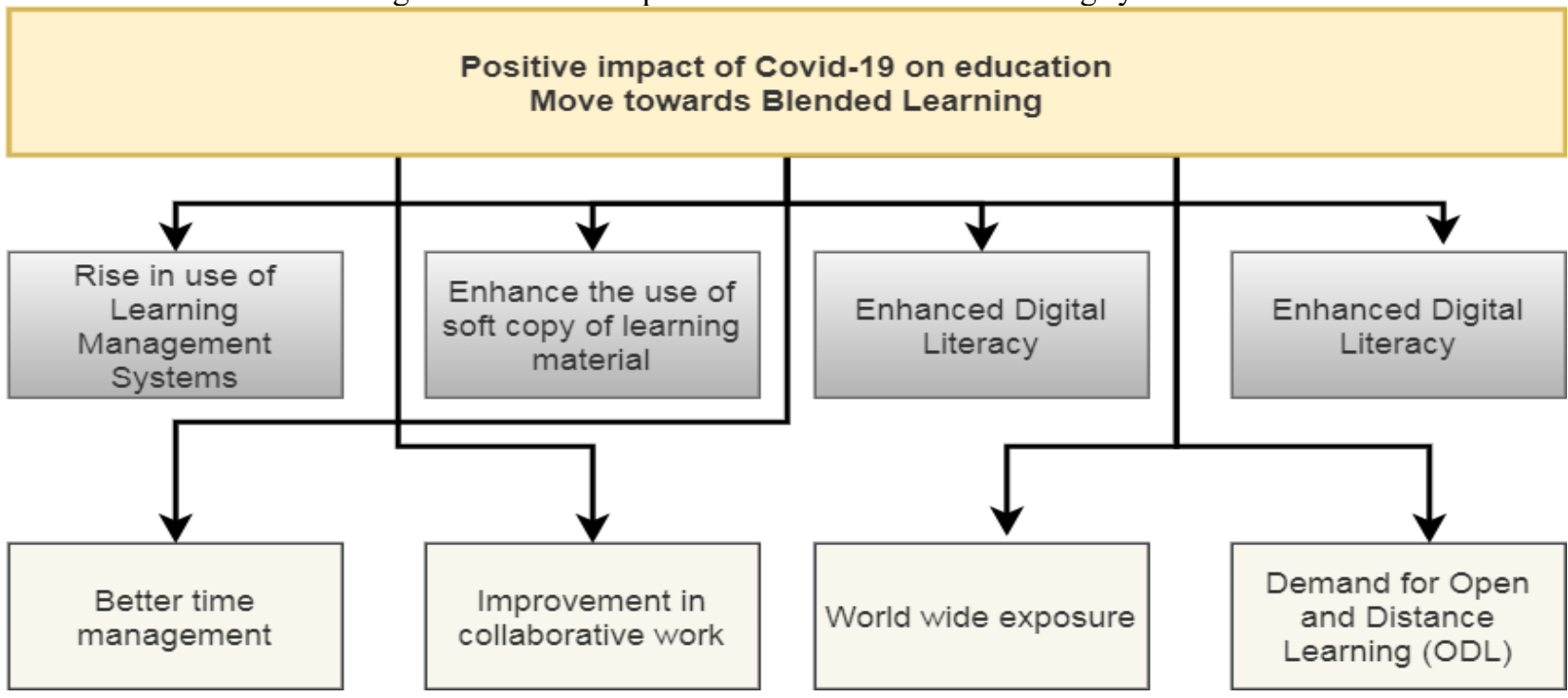

Figure 6: Negative impact of COVID-19 on the learning system.

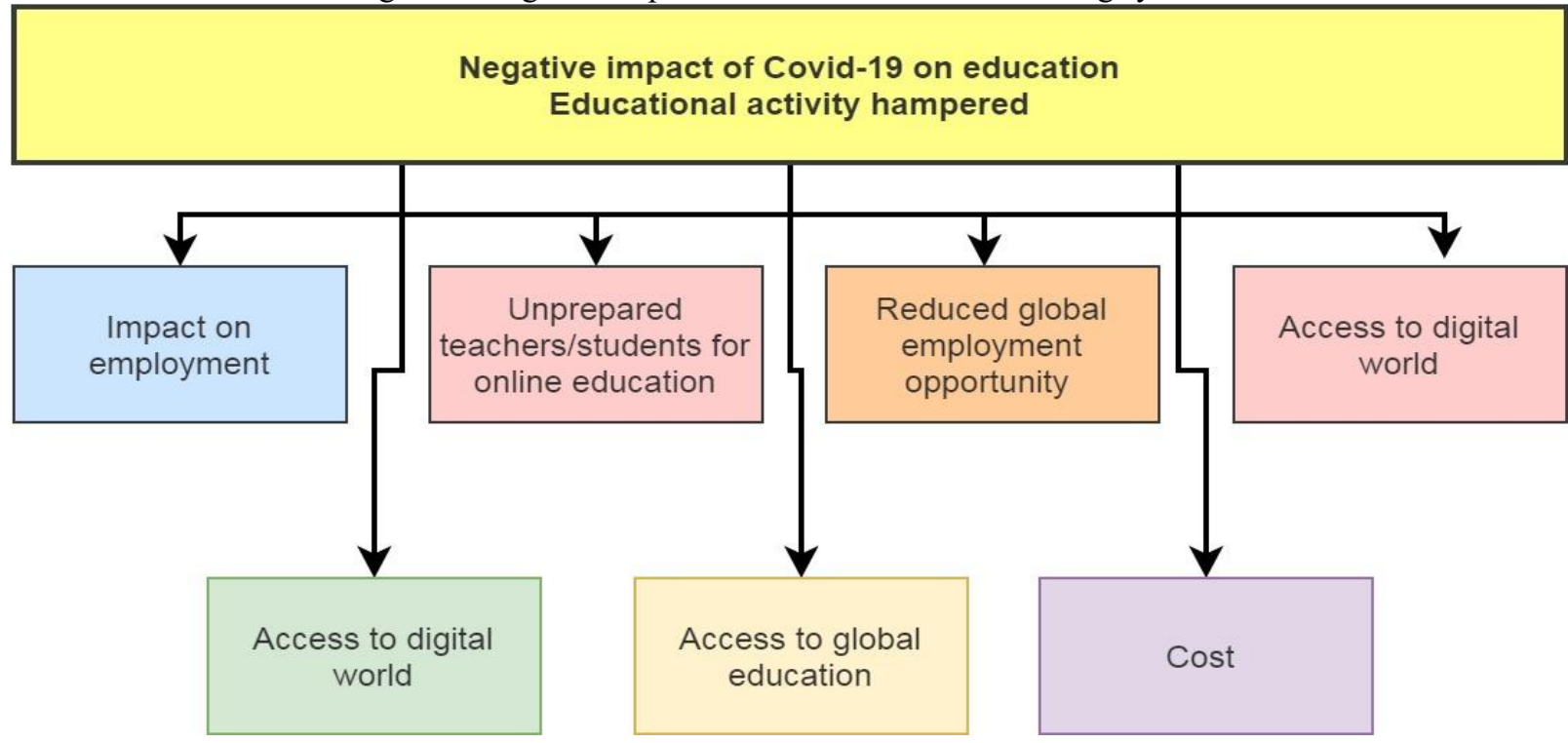

\subsection{Future Trends in Learning Systems}

There is an urgent need to create a ubiquitous learning environment by incorporating hybrid human intelligence into the loop to create safe, intelligent, and engaging online learning environments to promote performance and experience with learning services personalized as well as a huge online learning service, especially when they first appeared in the world. Some infectious diseases like COVID-19 emerge. Therefore, future work will be as follows. The intelligent knowledge service and online learning, undoubtedly, enable e-learners to learn and acquire knowledge [44]-[45]. At the same time, there are numerous scattered and chaotic online educational resources, causing low resource usage and learning efficiency. Hence, there is an urgent need to transfer numbers of educational resources into a cohesive knowledge system and service. Finally, the systematization of knowledge on the basis of the KG service leads to an orderly, thematic, and visual organization, management, and service of knowledge teaching. AR/VR services improve with the developing VR/AR technology, services with enhanced VR/AR online educational resources, including virtual physical resources and chemical experiments, and virtual design/green combustion engineering training will become popular, in particular with human-type personalized teaching assistants or intelligent agents with the integration of services such as $\mathrm{Q} / \mathrm{A}$ and effective interaction. Intelligent EQA systems, methods, and services still do not have scientific EQA since they have become a limitation to improving the e-learning quality [46]-[47]. Developing technology will be essential for the evaluation of production. Various types of assessment work together for the purpose of capturing and analyzing the abilities of online learners and online learning environments, taking into account full reliability, validity, fairness, and confidentiality, in establishing a mechanism for feedback and communication between learners and teachers, and then performing a thorough and scientific evaluation. Digital property protection or privacy services remain an important issue in online services. There is no exception for e-learning and its services. Certain tasks need to be performed for the prevention of 
confidentiality disclosure, including recommendations for sharing educational resources or facial identification. Some privacyrelated tasks are to ensure that there is no illegal leakage and to provide the modification of students' personal files on the Internet in digital repositories and educational resources [48].

\subsection{Limitations and Future Directions}

Although the present research has contributed to the literature significantly, there are several limitations in the current study, which can represent directions for future research. Firstly, the findings of the current research are primarily valid for developing countries where the development of e-learning systems is in the early phase. Nevertheless, e-learning systems have a good organization in the majority of the developed countries. It is necessary to conduct future studies in developed countries as a result of extending the framework of current studies. Secondly, the present research just provided the framework for e-learning systems. Nevertheless, universities are experiencing various difficulties in implementing e-learning systems. Thus, future research must address the challenges experienced by universities concerning the e-learning system and provide a potential solution. Thirdly, a questionnaire survey constitutes the basis of the current paper. However, future research should also involve interviews with higher authorities in universities to acquire precise information about online learning.

\section{Conclusions and Recommendations}

This paper presents the impact of the COVID-19 pandemic on the education system and mentions the affected geographical region and the faculty studied (age group/university and stream, duration of study). The COVID-19 pandemic has changed the entire world structure due to social distancing and also the education system. Therefore, it is necessary to apply digitalization to the education system critically. Furthermore, there is a need for a broader societal dialogue about the goals of education and about the society kind we want to develop in under the CCOVID-19 conditions. Despite the fact that the current study has made a considerable contribution to the literature and practice, it also has some limitations, which can be directions for future research. Firstly, the findings of this paper can primarily be applied to developing countries where the development of the online education system is in the beginning phase. Nevertheless, the majority of the developed countries have well-established online learning systems. It is necessary to conduct future studies in developed countries on the main issues of the cost of devices and network availability. Thirdly, a questionnaire survey constitutes the basis of the current paper. However, future research should also involve interviews with higher authorities in universities to acquire precise information about online learning.

\section{References}

[1] Markauskaite, L. (2006), Towards an integrated analytical framework of information and communications technology literacy: from intended to implemented and achieved dimensions, Information Research: an International electronic journal, 11(3):1-25.

[2] Huang, W., \& Mille, A. (2006), ConKMeL: a contextual knowledge management framework to support multimedia eLearning, Multimedia Tools and Applications, 30(2):205-219. https://doi.org/10.1007/s11042-006-0024-4.

[3] Caldwell, J. E. (2007), Clickers in the large classroom: Current research and best-practice tips, CBE-Life Sciences Education, 6(1): 9-20. https://doi.org/10.1187/cbe.06-12-0205

[4] Martin, A. (2008), Digital literacy and the "digital society", Digital literacies: Concepts, policies and practices, 30, 151176.

[5] Riddell, S., \& Weedon, E. (2014), Disabled students in higher education: Discourses of disability and the negotiation of identity, International Journal of Educational Research, 63, 38-46. https://doi.org/10.1016/j.ijer.2013.02.008

[6] Logica, B., \& Magdalena, R. (2015), Using big data in the academic environment, Procedia Economics and Finance, 33, 277-286. https://doi.org/10.1016/S2212-5671(15)01712-8

[7] Nordin, N. B., Mir, R. N., \& Noor, Z. (2017), Adoption of cloud computing in higher learning institutions: a systematic review, Indian Journal of Science and Technology, 10(36), 1-19, DOI: 10.17485/ijst/2017/v10i36/117641.

[8] Wang, Y., Kung, L., \& Byrd, T. A. (2018), Big data analytics: Understanding its capabilities and potential benefits for healthcare organizations. Technological Forecasting and Social Change, $\quad 126$, 3-13. https://doi.org/10.1016/j.techfore.2015.12.019

[9] Ullah, A.(2019), Artificial bee colony algorithm used for load balancing in cloud computing. IAES International Journal of Artificial Intelligence, 8(2), $156 . \quad$ DOI: 10.11591/ijai.v8.i2.pp156-167.

[10] Vu, T. N. (2020), Examining Teacher Agency Among Teacher Educators: An Action Research In Vietnam, Australian Journal of Teacher Education, 45(7), 6, DOI: 10.14221/ajte.2020v45n7.6.

[11] Lasuen, U. O., Iragorri, M. A. O., \& Diez, J. R. (2020), Towards energy transition at the Faculty of Education of Bilbao (UPV/EHU): diagnosing community and building, International Journal of Sustainability in Higher Education. https://doi.org/10.1108/IJSHE-12-2019-0363.

[12] Udok, M. B., Eton, C. U., \& Akpanika, E. N. (2020), Coronavirus Pandemic and its Effect on African Religiosity, International Journal of Humanities and Innovation (IJHI), 3(3), 109-114. https://doi.org/10.33750/ijhi.v3i3.86.

[13] Ullah, A., \& Nawi, N. M. (2020), Enhancing the dynamic load balancing technique for cloud computing using HBATAABC algorithm. International Journal of Modeling, Simulation, and Scientific Computing, 2050041 . https://doi.org/10.1142/S1793962320500415.

[14] Maphalala, M. C., \& Adigun, O. T. (2020), Academics' Experience of Implementing E-Learning in a South African Higher Education Institution, International Journal of Higher Education, 10(1), 2021. doi:10.5430/ijhe.v10n1p1.

[15] Sangster, A., Stoner, G., \& Flood, B. (2020), Insights into accounting education in a COVID-19 world, Accounting Education, 29(5), 431-562.

https://doi.org/10.1080/09639284.2020.1808487.

[16] Batur Dinler, Ö., Batur Şahin, C. (2021), Prediction of phishing web sites with deep learning using WEKA environment. European Journal of Science and Technology, (2021), 24, 35-41. https://doi.org/10.31590/ejosat.901465. 
[17] Hofmeister, C., \& Pilz, MUsing E-Learning to Deliver InService Teacher Training in the Vocational Education Sector: Perception and Acceptance in Poland, Italy and Germany. Education Sciences,. (2020). 10(7), 182. https://doi.org/10.3390/educsci10070182.

[18] Rapanta, C., Botturi, L., Goodyear, P., Guàrdia, L., \& Koole, M. Online university teaching during and after the Covid-19 crisis: Refocusing teacher presence and learning activity. Postdigital Science and Education, (2020). 2(3), 923945. https://doi.org/10.1007/s42438-020-00155-y.

[19] Shahzad, A., Hassan, R., Aremu, A. Y., Hussain, A., \& Lodhi, R. N. Effects of COVID-19 in E-learning on higher education institution students: the group comparison between male and female. Quality \& Quantity, (2020). 1-22. https://doi.org/10.1007/s11135-020-01028-z.

[20] Ullah, A., Nawi, N. M., Shahzad, A., Khan, S. N., \& Aamir, M. (2017), An e-learning system in Malaysia based on green computing and energy level, JOIV: International Journal on Informatics Visualization, 1(4-2), 184-187. http://dx.doi.org/10.30630/joiv.1.4-2.63

[21] De Amicis, R., Riggio, M., Badr, A. S., Fick, J., Sanchez, C. A., \& Prather, E. A. (2019), Cross-reality environments in smart buildings to advance STEM cyberlearning, International Journal on Interactive Design and Manufacturing (IJIDeM), 13(1), 331-348.

[22] Crawford, J., Butler-Henderson, K., Rudolph, J., Malkawi, B., Glowatz, M., Burton, R., \& Lam, S. (2020), COVID-19: 20 countries' higher education intra-period digital pedagogy responses. Journal of Applied Learning \& Teaching, 3(1), 120. http://dx.doi.org/10.37074/jalt.2020.3.1.7

[23] Azevedo, J. P., Hasan, A., Goldemberg, D., Iqbal, S. A., \& Geven, K. (2020), Simulating the potential impacts of COVID-19 school closures on schooling and learning outcomes: A set of global estimates. https://doi.org/10.1596/1813-9450-9284.

[24] Harris, B. N., McCarthy, P. C., Wright, A. M., Schutz, H., Boersma, K. S., Shepherd, S. L., \& Ellington, R. M. (2020), From panic to pedagogy: Using online active learning to promote inclusive instruction in ecology and evolutionary biology courses and beyond. Ecology and Evolution. https://doi.org/10.1002/ece3.6915.

[25] Shehzadi, S., Nisar, Q. A., Hussain, M. S., Basheer, M. F., Hameed, W. U., \& Chaudhry, N. I. (2020), The role of digital learning toward students' satisfaction and university brand image at educational institutes of Pakistan: a post-effect of COVID-19. Asian Education and Development Studies. https://doi.org/10.1108/AEDS-04-2020-0063.

[26] Ali, F., Zhou, Y., Hussain, K., Nair, P. K., \& Ragavan, N. A. (2016), Does higher education service quality effect student satisfaction, image and loyalty?. Quality assurance in education. https://doi.org/10.1108/QAE-02-2014-0008

[27] Orel, F. D., \& Kara, A. (2014), Supermarket self-checkout service quality, customer satisfaction, and loyalty: Empirical evidence from an emerging market. Journal of Retailing and Consumer Services, 21(2), 118-129. https://doi.org/10.1016/i.jretconser.2013.07.002.

[28] Lowry, P. B., \& Gaskin, J. (2014), Partial least squares (PLS) structural equation modeling (SEM) for building and testing behavioral causal theory: When to choose it and how to use it. IEEE transactions on professional communication,57(2), 123-146. https://doi.org/10.1109/TPC.2014.2312452.

[29] Cole, D. A., Maxwell, S. E., Arvey, R., \& Salas, E. (1993), Multivariate group comparisons of variable systems:
MANOVA and structural equation modeling. Psychological Bulletin, 114 (1), 174.

https://psycnet.apa.org/doi/10.1037/0033-2909.114.1.174.

[30] Musil, C. M., Jones, S. L., \& Warner, C. D. Structural equation modeling and its relationship to multiple regression and factor analysis. Research in Nursing \& Health, (1998). 21(3), 271-281.https://doi.org/10.1002/(SICI)1098240X(199806)21:3\%3C271::AID-NUR10\%3E3.0.CO;2-G

[31] Hair Jr, J. F., Hult, G. T. M., Ringle, C., \& Sarstedt, M. (2016), A primer on partial least squares structural equation modeling (PLS-SEM). Sage publications.

[32] Ulaganathan, M., Nithya, R., \& Rajendran, S. (2012), Surface analysis studies on polymer electrolyte membranes using scanning electron microscope and atomic force microscope. In Scanning Electron Microscopy. Intechopen. (2012). DOI: $10.5772 / 34948$.

[33] Yang, R., Zhang, S., Zhang, L., \& Liu, W. (2013), Electrical properties of composite polymer electrolytes based on PEOSN-LiCF3SO3. Int. J. Electrochem. Sci, 8, 10163-10169.

[34] Gajendran, N. (2020), Blockchain-Based secure framework for elearning during COVID-19. Indian journal of science and technology, 13(12), 1328-1341.

https://doi.org/10.17485/IJST/v13i12.152.

[35] Sathishkumar, V. \& Radha, R. \& Saravanakumar, Ar \& Mahalakshmi, K.. (2020), E-Learning during Lockdown of Covid-19 Pandemic: A Global Perspective. International Journal of Control and Automation. 13. 1088-1099.

[36] Mpungose, C.B.(2020), Emergent transition from face-toface to online learning in a South African University in the context of the Coronavirus pandemic. Humanit Soc Sci Commun 7, 113. https://doi.org/10.1057/s41599-020-00603$\underline{\mathrm{x}}$

[37] Al-Balas, M., Al-Balas, H.I., Jaber, H.M. et al. (2020), Distance learning in clinical medical education amid COVID19 pandemic in Jordan: current situation, challenges, and perspectives. BMC Med Educ 20, 341. https://doi.org/10.1186/s12909-020-02257-4.

[38] Armstrong-Mensah, Elizabeth; Ramsey-White, Kim; Yankey, Barbara; Self-Brown, Shannon (2020), COVID-19 and Distance Learning: Effects on Georgia State University School of Public Health Students. Frontiers in Public Health, 8(), 576227-. doi:10.3389/fpubh.2020.576227.

[39] Mulla, Z. D., Osland-Paton, V., Rodriguez, M. A., Vazquez, E., \& Kupesic Plavsic, S. (2020), Novel coronavirus, novel faculty development programs: rapid transition to eLearning during the pandemic, Journal of Perinatal Medicine, 48(5), 446-449. doi: https://doi.org/10.1515/jpm-2020-0197.

[40] Nugroho, R. A., Basari, A., Suryaningtyas V.W., \& Cahyono, S.P. (2020), University Students' Perception of Online Learning in Covid-19 Pandemic: A Case Study in a Translation Course, 2020 International Seminar on Application for Technology of Information and Communication (iSemantic), Semarang, Indonesia, pp. 225 231, doi: 10.1109/iSemantic50169.2020.9234251.

[41] Murphy, M. P. A. (2020), COVID-19 and emergency eLearning: Consequences of the securitization of higher education for post-pandemic pedagogy, Contemporary Security Policy, 41:3, 492-505, DOI: 10.1080/13523260.2020.1761749.

[42] Oztemel, E., \& Gursev, S. (2020), Literature review of Industry 4.0 and related technologies. Journal of Intelligent Manufacturing, 31(1), 127-182. 
[43] Bao, W. (2020), COVID-19 and online teaching in higher education: A case study of Peking University. Hum Behav \& Emerg Tech. 2: 113- 115. https://doi.org/10.1002/hbe2.191.

[44] Yanti, B., Wahyudi, E., Wahiduddin, W., Novika, R. G. H., Arina, Y. M. D. A., Martani, N. S., \& Nawan, N. (2020), Community knowledge, attitudes, and behavior towards social distancing policy as prevention transmission of COVID-19 in indonesia. Jurnal Administrasi Kesehatan Indonesia, 8(2), 414.

[45] Sugarman, J. R., Warren, C. W., Oge, L., \& Helgerson, S. D. (1992), Using the Behavioral Risk Factor Surveillance System to monitor year 2000 objectives among American Indians. Public Health Reports, 107(4), 449.

[46] Moore, L. V., Dodd, K. W., Thompson, F. E., Grimm, K. A., Kim, S. A., \& Scanlon, K. S. (2015), Using behavioral risk factor surveillance system data to estimate the percentage of the population meeting US Department of Agriculture food patterns fruit and vegetable intake recommendations. American journal of epidemiology, 181(12), 979-988.

[47] Wijaya, I. K. (2012), Environmental Influences Cause Stress on the Use of Computer. International Journal of Public Health Science, 1(1), 7253.

[48] Boadu, R. O., Agyei-Baffour, P., \& Edusei, A. K. (2019), Data accuracy and completeness of monthly midwifery returns indicators of Ejisu Juaben Health Directorate of Ghana. International Journal of Public Health Science, 8(1), 106-117. 